\title{
Identifikasi Perkembangan Virus Infectious Bronchitis Isolat Lokal Dan Massachusetts Pada Cairan Allantois TAB Dengan Indirect Fluorescence Antibody Technique
}

\author{
(IDENTIFICATION OF THE DEVELOPMENT OF INFECTIOUS BRONCHITIS \\ VIRUSES IN LOCAL AND MASSACHUSETTS ISOLATES IN ALLANTOIC FLUIDS \\ TAB WITH INDIRECT FLUORESCENCE ANTIBODY TECHNIQUE)
}

\author{
Githa Nurma Aziz ${ }^{1 *}$, Suwarno², Ratih Novita Praja², Jola Rahmahani², Prima Ayu \\ Wibawati ${ }^{3}$, Faisal Fikri ${ }^{4}$ \\ ${ }^{1}$ Bachelor of Veterinary Medicine, \\ ${ }^{2}$ Department of Veterinary Microbiology, \\ ${ }^{3}$ Department of Veterinary Public Health, \\ ${ }^{4}$ Department of Basic Veterinary Science, \\ Faculty of Veterinary Medicine, Universitas Airlangga, \\ UNAIR C-Campus Mulyorejo, Surabaya, Jawa Timur, Indonesia, 60115 \\ Telp. (031)5993016, Fax. (031)5993015 \\ *Corresponding author: githa.nurma.aziz-2014@fkh.unair.ac.id
}

\begin{abstract}
Abstrak
Virus Infectious Bronchitis merupakan penyakit yang disebabkan oleh genus Gammacoronavirus, subfamili Coronavirinae, famili Coronavirinae tidak bersegmen, sense positif dengan genom SS-RNA. Terdapat lebih dari 30 macam serotip virus infectious bronchitis yang ditemukan. Penelitian ini bertujuan untuk mengetahui perkembangan virus infectious bronchitis isolat lokal (PTS-III) dan Massachusetts yang di inokulasikan pada cairan allantois TAB. Identifikasi dilakukan berdasarkan waktu inkubasi virus IB yakni dengan waktu 0 jam, 6 jam, 12 jam, 24 jam, 48 jam, 72 jam, 96 jam dan 120 jam dan kemudian di panen. Isolasi virus IB dilakukan secara in ovo pada telur ayam berembrio (TAB) umur 9 hingga 11 hari. Menggunakan ulangan 3 butir TAB pada setiap waktu inkubasi dengan total TAB berjumlah 50 butir. Inokulum disuntikkan ke dalam cairan allantois dengan spuit $1 \mathrm{ml}$ secara tegak lurus dengan kantung hawa. Metode pemeriksaan yang digunakan menggunakan Indirect FAT dan mikroskop fluorescence dengan melihat adanya perpenderan cahaya neon atau fluoresensi. Hasil data yang digunakan secara kualitatif yang disajikan dalam bentuk tabel dengan hasil berupa positif dan negatif. Pada penelitian ini menunjukkan adanya hasil negatif pada TAB yang di inkubasi hingga jam ke-0 dan jam ke-6. Hasil positif ditunjukkan pada TAB yang di inkubasi pada jam ke-12, $24,48,72,96$ dan 120 .
\end{abstract}

Kata kunci: infectious bronchitis, Fluorescence Antibodi Technique (FAT), telur ayam berembrio (TAB)

Abstract

This study aims to determine the replication of local isolates (PTS-III) and Massachusetts of infectious bronchitis virus that inoculated to the allantoic fluid of embryonated chicken eggs. The identification is based on the incubation time of IB virus with some kind of time 0, 6, 12, 24, 48, 72, 96 and 120 hours. IB virus isolation performed in ovo on embryonated chicken eggs aged 9-11 days. Used to 3 point of embryonated chicken eggs replicates at each time of incubation with embryonated chicken eggs total of 50 items include negative control. The inoculum was injected into the allantoic fluid with syringe volume $1 \mathrm{ml}$ on vertical through the air bag of egg. Candling is done at the time of harvesting the embryonated chicken eggs to ensure the condition of the embryo. Inspection methods used to Indirect FAT and fluorescent microscopy to see the neon light fluorescence. The equipment used to inspectiopn is Nikon H-600L microscope and NIS-Elements BR 4.10.00 aplication tho show the fluorescence. In this study showed a negative result on a embryonated chicken eggs is incubation for 0 hour. The positive results shown in embryonated chicken eggs start from 6 hour of incubation until 12, 24, 48, 72, 96 and 120 hours. Positive results with the presence of fluorescent is indicate the presence of viral replication of infectious bronchitis.

Key words: infectious bronchitis, Fluorescent Antibody Technique (FAT), embryonated chicken eggs 


\section{PENDAHULUAN}

Beberapa macam jenis penyakit dapat menyerang ayam tetapi gejala yang ditimbulkan memiliki perbedaan sehingga menyebabkan peternak melakukan kesalahan dalam pengobatan (Nurcahya, 2017). Penyakit yang dapat menyerang ayam ras dan ayam kampung adalah Infectious Bronchitis (IB). Menurut Tarmudji dan Mulyadi (2006), pada beberapa peternakan ayam di Jawa Barat masih memiliki tingkat prevalensi penyakit IB $40 \%$ sampai $60 \%$. Varian virus IB yang cukup tinggi menyebabkan banyaknya virus di lapangan sehingga tindakan vaksinasi tidak lagi efektif. Isolasi dan identifikasi isolat virus IB penting dilakukan berdasarkan serotipe yang ada pada wilayah tertentu agar program vaksinasi efektif dilakukan.

Diagnosis penyakit di lapangan berdasarkan gejala klinis dan patologi makroskopis yang terlihat. Patologi makroskopis digunakan sebagai pendukung terhadap diagnosis yang dinyatakan sebagai bentuk konfirmasi. Telur ayam berembrio memiliki kepekaan terhadap sifatnya sebagai media perkembangan virus dengan metode yang paling sederhana dan dapat digunakan untuk isolasi virus (Dharmayanti dkk, 2005). Isolasi menggunakan telur ayam berembrio (TAB) dengan umur 9 sampai 11 hari dan dilakukan inokulasi pada cairan allantois (Tarmudji dan Mulyadi, 2006).

Virus dapat di biakkan dalam media kultur jaringan atau dalam telur berembrio dengan kondisi lingkungan yang dikendalikan (Jawetz, 1996). Virus akan melakukan replikasi menggunakan komponen makromolekular untuk mengambil energi sel hospes sehingga fungsi sel hospes terganggu (Radji, 2010). Telur berembrio seperti telur ayam berembrio (TAB) telah lama digunakan sebagai media isolasi virus. Metode pengujian in ovo merupakan salah satu media penumbuh berbagai macam virus yang memiliki keunggulan dibandingkan pengujian in vitro dengan menggunakan kultur sel karena tidak membutuhkan media dan kondisi laboratorium yang sulit (Murtini dkk., 2006).
Identifikasi virus dapat dilakukan dengan berbagai teknik pengujian, baik secara konvensional maupun teknik molekuler (Hewajuli dan Dharmayanti, 2014). Menurut OIE (2013), uji Fluourescence Antibody Technique merupakan uji yang dapat digunkan untuk melihat adanya virus yang muncul pada cairan allantois yang terinfeksi. Uji ini direkomendasikan oleh WHO dan OIE karena memiliki tingkat spesifisitas 98-99\%. Pemeriksaan dilakukan berdasarkan pada metode pelabelan antibodi dengan pewarnaan fluorochrom menggunakan fluorescene sehingga akan memberi warna hijau-kuning saat diperiksa pada mikroskop fluorescence (Suwarno, 2005). Penelitian ini bertujuan untuk mengetahui adanya perkembangan virus IB isolat lokal dan Massachusetts yang diinokulasikan pada telur ayam berembrio (TAB) di dalam cairan allantois dengan pemeriksaan Indirect Fluorescence Antibodi Technique.

\section{METODE PENELITIAN}

Penelitian ini dilakukan di Laboratorium Virologi dan Imunologi Departemen Mikrobiologi Fakultas Kedokteran Hewan Universitas Airlangga Surabaya. Pemeriksaan dengan mikroskop fluorescent dilakukan di Laboratorium Patologi Fakultas Kedokteran Hewan Universitas Airlangga. Sampel virus IB didapat dari koleksi Departemen Mikrobiologi Veteriner Fakultas Kedokteran Hewan Universitas Airlangga Surabaya.

Bahan yang digunakan pada penelitian ini yakni virus IB isolat lokal (PTS-III) dan serotip Massachusetts, telur ayam berembrio (TAB) umur 10 hari sejumlah 50 butir, PBS, Antibiotik (penisilin dan streptomisin). Bahan yang digunakan untuk pemeriksaan Indirect Fluourescence Antibodi Technique (FAT) meliputi aquades, aceton absolut dingin $80 \%$, larutan PBS, antibodi primer anti-virus IB asal ayam dan kelinci yakni anti-rabbit/anti-chicken

1:100 $\mu \mathrm{l}$, konjugat antibodi sekunder IB berlabel FITC, buffer glycerin 1:1. Alat yang digunakan yakni pelubang telur, selotip kertas, 
kapas steril, egg tray, gunting, gelas obyek, gelas penutup, cawan Petri, gelas beaker, tabung/ampul, inkubator $37^{\circ} \mathrm{C}$, lemari pendingin, coolbox, mikropipet, spuit $1 \mathrm{ml}$, egg candler, mikroskop fluorescent Nikon H-600L ${ }^{\circledR}$, aplikasi NIS-elements BR 4.10.00 (Wibowo dan Asmara, 2002).

Pemeriksaan FAT menggunakan mikroskop fluorescence pada pembesaran 100x hingga 1000x. Jika positif hasil yang didapatkan pada preparat akan terlihat pancaran warna hijau terang atau apple green. Jika negatif warna hijau tidak terlihat pada mikroskop fluorescence (Lapatra, 1989). Pengamatan terhadap ekspresi perkembangan virus dilakukan dengan memberi nilai (+) positif pada hasil yang menunjukkan bentukan warna fluorescent. Nilai (-) negatif pada hasil yang tidak menunjukkan bentukan warna fluorescence (Lapatra, 1989).

Penyajian data dalam penelitian ini dilakukan secara deskriptif kualitatif dengan menghitung presentasi sampel positif untuk menghitung adanya perkembangan virus IB pada cairan allantois TAB pada isolat lokal dan serotip Masschussets pada waktu inkubasi yang telah ditentukan. Sampel negatif dihitung untuk melihat presetasi tidak adanya perkembangan virus IB pada cairan allantois TAB.

\section{HASIL DAN PEMBAHASAN}

Pada tabel 1. virus IB mulai berkembang dengan waktu inkubasi 6 jam pada cairan allantois. Hasil panen virus IB isolat lokal (PTS3) embrio mulai mengalami kematian pada waktu inkubasi jam ke-48. Kematian embrio terjadi pada waktu inkubasi jam ke-72, 96, 120 dengan waktu kematian yang berbeda. Rerata waktu kematian embrio pada TAB setelah di inokulasi (PTS-III) adalah pada waktu inkubasi jam ke-48 dan 72. Pada virus IB (Massachusetts) embrio mulai mengalami kematian pada waktu inkubasi jam ke-48. Kematian embrio tertinggi atau paling banyak mengalami kematian terdapat pada waktu inkubasi jam ke-96.

Menurut De Wit (2000), virus Infectious Bronchitis dapat tumbuh baik pada embrio yang sedang berkembang dan mencapai cairan allantois dengan maksimal mulai 24 sampai 48 jam setelah dilakukan inokulasi. Membran korioalantois merupakan fusi dari korion dan allantois yang mulai terjadi pada hari ke-5 inkubasi dan terbentuk sempurna pada hari ke11. Membran ini tersusun atas lapisan sel-sel epitel yang kaya akan pembuluh darah. Jumlah dan kerapatan pembuluh darah di membran korioalantois terus meningkat seiring dengan pertambahan usia dan perkembangan embrio. Kerusakan epitel pembuluh darah akan menghambat proses pertukaran oksigen dan karbondioksida pada membran tersebut. Kadar oksigen yang rendah menyebabkan terjadinya anoksia sel yang akan mempercepat proses kematian sel (Reizis et al., 2005).

Pemeriksaan indirect FAT yang menunjukkan hasil postif (+) akan fluouresensi. Menurut Mutia (2011), intensitas pendaran cahaya yang semakin lemah mengindikasikan virus yang bereplikasi pada sel memiliki titer yang rendah. indirect FAT menggunakan antibodi primer yang tidak dilabel yang direaksikan antibodi sekunder berlabel fluorescence (Buchalow \& Bocker, 2010). Antibodi akan berikatan dengan protein virus infectious bronchitis yakni protein $\mathrm{S}$ dengan subunit S1 dan S2 pada permukaan atau bagian dalam dari sel yang terinfeksi (Tabbu, 2000). Pemeriksaan dengan mikroskop fluorescence waktu inkubasi jam ke-12, 24, 48, 72, 96, 120 menunjukkan hasil positif. Perpendaran cahaya neon atau fluoresensi merupakan indikasi hasil positif.

Berdasarkan tabel 2. pada virus IB isolat lokal (PTS-III) dan Massachusetts dengan waktu inkubasi 0 jam menunjukkan hasil negatif (-). Pemeriksaan dengan mikroskop fluorescence tidak ditemukan adanya fluoresensi akibat virus IB isolat lokal (PTS-III) dan Massachusetts belum terjadi perkembangan. Hasil pemeriksaan indirect FAT pada cairan allantois Massachusetts dan PTS-III mulai terlihat fluoresensi pada waktu inkubasi 6 jam. Virus IB yang di inokulasikan pada TAB akan mulai berkembang pada cairan allantois maksimal pada 24 sampai 48 jam setelah inokulasi (De Wit, 2000). 
Tabel 1. Hasil pertumbuhan virus Infectious Bronchitis pada cairan allantois TAB

\begin{tabular}{ccccccc}
\hline \multirow{2}{*}{ Waktu Inkubasi } & \multicolumn{3}{c}{ Massachusetts } & \multicolumn{3}{c}{ Isolat local (PTS-III) } \\
\cline { 2 - 7 } & TAB 1 & TAB 2 & TAB 3 & TAB 1 & TAB 2 & TAB 3 \\
\hline 0 jam & + & + & + & + & + & + \\
6 jam & + & + & + & + & + & + \\
$12 \mathrm{jam}$ & + & + & + & + & + & + \\
$24 \mathrm{jam}$ & + & + & + & + & + & + \\
$48 \mathrm{jam}$ & + & $-(48 \mathrm{jam})$ & + & + & $-(48 \mathrm{jam})$ & + \\
$72 \mathrm{jam}$ & + & $-(72 \mathrm{jam})$ & + & $-(48 \mathrm{jam})$ & + & + \\
$96 \mathrm{jam}$ & + & $-(72 \mathrm{jam})$ & $-(72 \mathrm{jam})$ & + & $-(96 \mathrm{jam})$ & $-(72 \mathrm{jam})$ \\
$120 \mathrm{jam}$ & $-(72 \mathrm{jam})$ & + & $-(72 \mathrm{jam})$ & + & $-(96 \mathrm{jam})$ & + \\
\hline
\end{tabular}

Keterangan: (+) kondisi embrio hidup, (-) kondisi embrio mati

Tabel 2. Hasil pemeriksaan virus Infectious Bronchitis pada cairan allantois dengan Indirect FAT

\begin{tabular}{ccc}
\hline \multirow{2}{*}{ Waktu Inkubasi } & \multicolumn{3}{c}{ Isolat } \\
\cline { 2 - 3 } & Massachusetts & Isolat Lokal (PTS-III) \\
\hline 0 jam & - & - \\
6 jam & + & + \\
12 jam & + & + \\
24 jam & + & + \\
48 jam & + & + \\
72 jam & + & + \\
96 jam & + & + \\
121 jam & + & + \\
\hline
\end{tabular}

Keterangan: Hasil Indirect FAT (+) positif ada flouresensi; (-) negatif tidak ada flouresensi

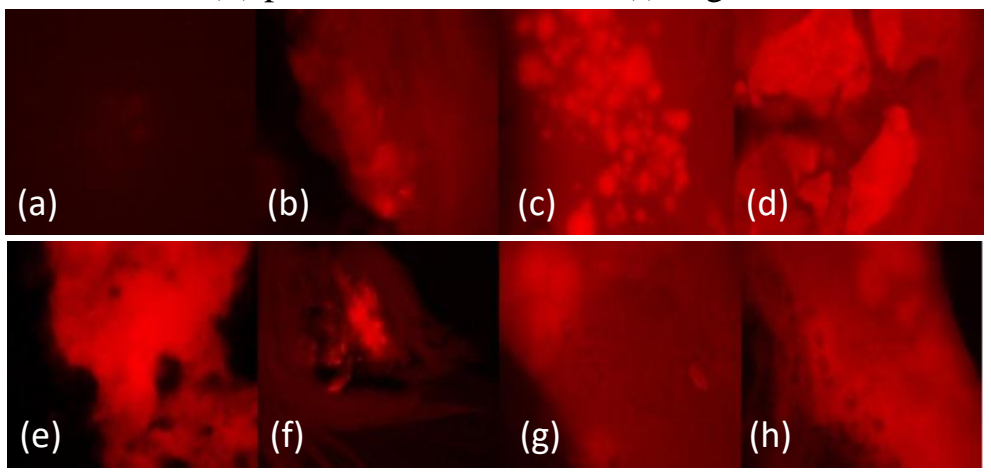

Gambar 1. Hasil Pemeriksaan Indirect FAT virus IB isolat lokal (PTS-III); (a) 0 jam (b) 6 jam (c) 12 jam (d) 24 jam (e) 48 jam (f) 72 jam (g) 96 jam (h) 120 jam

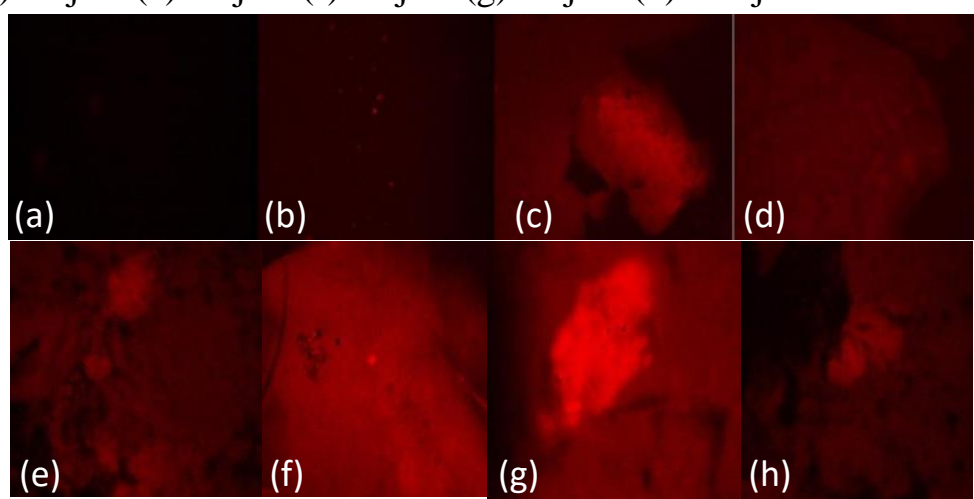

Gambar 2. Hasil Pemeriksaan Indirect FAT virus IB isolat Massachusetts; (a) 0 jam (b) 6 jam (c) 12 jam (d) 24 jam (e) 48 jam (f) 72 jam (g) 96 jam (h) 120 jam 
Pemeriksaan dengan mikroskop fluorescence waktu inkubasi jam ke-12, 24, 48, 72, 96, 120 menunjukkan hasil positif. Perpendaran cahaya neon atau fluoresensi merupakan indikasi hasil positif. Virus IB yang di inokulasikan pada TAB akan mulai berkembang pada cairan allantois.

Menurut Mutia (2011), intensitas pendaran cahaya yang semakin lemah mengindikasikan virus yang bereplikasi pada sel memiliki titer yang rendah. indirect FAT menggunakan antibodi primer yang tidak dilabel yang direaksikan antibodi sekunder berlabel fluorescence (Buchalow \& Bocker, 2010). Antibodi akan berikatan dengan protein virus infectious bronchitis yakni protein $\mathrm{S}$ dengan subunit $\mathrm{S} 1$ dan $\mathrm{S} 2$ pada permukaan atau bagian dalam dari sel yang terinfeksi (Tabbu, 2000).

\section{KESIMPULAN}

Indirect Fluorescence Antibody Technique mampu mengidentifikasi perkembangan virus Infectious Bronchitis isolat lokal (PTS-III) dan Massachusetts mulai waktu inkubasi 6, 12, 24, 48, 72, 96 dan 120 jam setelah dilakukan inokulasi pada cairan allantois TAB.

\section{UCAPAN TERIMA KASIH}

Peneliti mengucapkan terima kasih kepada Laboratorium Imunologi dan Virologi FKH Universitas Airlangga yang telah membantu sehingga penelitian berjalan lancar.

\section{DAFTAR PUSTAKA}

Nurcahya, D.E. 2017. Klasifikassi Penyakit Ayam Menggunakan Metode Support Vector Machine. Ponorogo: Universitas Muhammadiyah Ponorogo.

OIE. 2013. Infectious Bronchitis. Chapter 2.3.2.

Tarmudji dan Mulyadi. 2006. Kegagalan Vaksinasi IB Pada Ayam. Tabloid Sinar Tani. Balivet Bogor.
Dharmayanti, I., Asmara, W., Artama, W.T., Indriani, R., Darminto. 2005. Hubungan Kekerabatan Virus IB Isolat Lapang Indonesia. J Bioteknologi Pertanian, 10,1523.

Jawetz, E. 1996. Mikrobiologi Klinik. Jakarta: Penerbit Buku EGC.

Radji, M. 2010. Imunologi Dan Virologi. Jakarta: PT Isfi Penerbitan.

Reizis, A., Hammel, I. 2005. Regional And Developmental Variations Of Blood Vessel Morphometry In The Chick Embryo Chorioallantoic Membrane. J. Exp. Biol., 208, 2483-2488.

Murtini, S., Murwani, R., Satrija, F., Malole. 2006. Penetapan Rute Dan Dosis Inokulasi Pada Telur Ayam Berembrio Sebagai Media Uji Khasiat Ekstrak Benalu Teh (Scurrula Oortiana). Semarang: Departemen Ilmu Penyakit Hewan Dan Kesehatan, Fakultas Kedokteran Hewan, Institut Pertanian Bogor.

Mutia, K. 2011. Optimasi Uji Imunofluoresensi Untuk Mendeteksi dan Membedakan Serotipe Virus Dengue. Skripsi: Universitas Indonesia.

Hewajuli, D.A., Dharmayanti. 2014. Perkembangan Teknologi Reverse Transcription-Polymerase Chain Reaction Dalam Mengidentifikasi Genom Avian Influenza dan Newcastle Disease. Balai Besar Veteriner Bogor.

Suwarno. 2005. Identifikasi Virus Rabies Yang Diadaptasi Pada Kultur Sel Nerobastoma Dengan Indirect Sandwich Elisa Dan Direct Fat. Surabaya: Bagian Mikrobiologi Fakultas Kedokteran Hewan Universitas Airlangga, 21(1).

De Wit, J.J. 2000. Technical Review Detection of infectious bronchitis virus. Avian pathol., 1, 71-93. 


\section{Buchalow, I.B., $\quad$ Bocker. 2010.}

Faslah, R. 2011.Studi Seroprevalensi Infectious Bronchitis Pada Ayam Kampung Di Kecamatan Cipunegara, Kabupaten Subang. Skripsi. Fakultas Kedokteran Hewan Institut Pertanian Bogor.
Immunohistochemistry: Basic And Method. Springer Verlag, Berlin Heidelberg. p150.

Tabbu, C.R. 2000. Penyakit Ayam Dan Penanggulangannya. Penyakit Bakterial, Mikal dan Viral. Volume 1. Kanisius. Yogyakarta. 